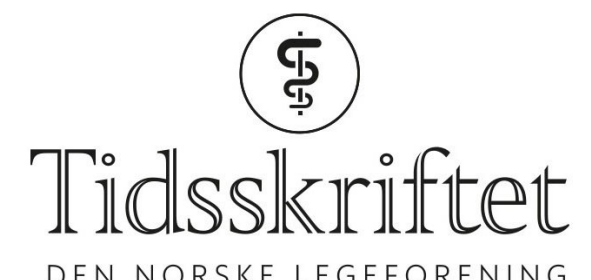

DEN NORSKE LEGEFORENING

\title{
Akutt telefonisk varsling om avvikende farmakologiske prøvesvar
}

\author{
DEBATT

\section{TROND TRETTEBERG SERKLAND} \\ E-post: trond.tretteberg.serkland@helse-bergen.no \\ Trond Trætteberg Serkland er lege i spesialisering ved Seksjon for klinisk farmakologi, Avdeling for \\ medisinsk biokjemi og farmakologi, Haukeland universitetssykehus. \\ Forfatter har fylt ut ICMJE-skjemaet og oppgir ingen interessekonflikter.
}

\section{ILAH LE NYGAARD}

Ilah Le Nygaard er overlege ved Seksjon for klinisk farmakologi, Avdeling for farmakologi, Oslo universitetssykehus.

Forfatter har fylt ut ICMJE-skjemaet og oppgir ingen interessekonflikter.

\section{ELENA KVAN}

Elena Kvan er overlege ved Seksjon for klinisk farmakologi, Avdeling for medisinsk biokjemi, Drammen sykehus.

Forfatter har fylt ut ICMJE-skjemaet og oppgir ingen interessekonflikter.

\section{JOACHIM FROST}

Joachim Frost er overlege ved Avdeling for klinisk farmakologi, St. Olavs hospital. Forfatter har fylt ut ICMJE-skjemaet og oppgir ingen interessekonflikter.

\section{LENA ARONSEN}

Lena Aronsen er overlege ved Klinisk farmakologi, Laboratoriemedisin, Universitetssykehuset NordNorge.

Forfatter har fylt ut ICMJE-skjemaet og oppgir ingen interessekonflikter.

\section{SIGRID NARUM}

Sigrid Narum er overlege ved Senter for psykofarmakologi, Diakonhjemmet sykehus. Forfatter har fylt ut ICMJE-skjemaet og oppgir ingen interessekonflikter.

\section{TORMOD BJÅNES}

Tormod Bjånes er overlege ved Seksjon for klinisk farmakologi, Avdeling for medisinsk biokjemi og farmakologi, Haukeland universitetssykehus.

Forfatter har fylt ut ICMJE-skjemaet og oppgir ingen interessekonflikter.

Det foreligger nå en oversikt over når laboratoriet umiddelbart bør varsle klinikeren om avvikende farmakologiske prøvesvar der pasientens helse og liv kan stå i fare.

I enkelte tilfeller rekvireres analyser av legemidler eller andre kroppsfremmede stoffer, som metanol, hvor det viser seg at serumkonsentrasjonen hos pasienten er så avvikende at det er 
fare for liv og helse. I disse tilfellene bør laboratoriet så snart som mulig varsle behandlende lege per telefon. Disse grensene defineres som «varslingsgrenser». Stor variasjon mellom laboratorier og uttrykte ønsker fra enkeltpersoner i fagmiljøet har tydeliggjort et behov for harmonisering av disse grensene på tvers av landets laboratorier.

Styret i Norsk forening for klinisk farmakologi (NFKF) satt derfor ned en arbeidsgruppe (1). Arbeidsgruppen var bredt sammensatt med representanter fra de klinisk farmakologiske miljøene i Norge. Målet var å oppnå konsensus om anbefalte varslingsgrenser for de hyppigst tilbudte farmakologiske analysene i Norge (2). En utfyllende rapport, som nå er publisert på farmakologiportalen.no, gir en oversikt over bakgrunnen for grensene som er anbefalt $(3,4)$.

Forslag til anbefalte varslingsgrenser ble utarbeidet gjennom litteraturs $\varnothing \mathrm{k}$ og flere høringsrunder. Både klinisk farmakologiske laboratorier og fagpersoner i ulike medisinske spesialiteter ble inkludert. Anbefalingene fremgår i tabell 1. Tabellen er særlig ment som et hjelpemiddel for laboratorier der klinisk farmakologisk fagkompetanse ikke er umiddelbart tilgjengelig. Anbefalingene er veiledende, og lokale tilpasninger kan være nødvendig.

\section{Tabell 1}

Arbeidsgruppens anbefalte varslingsgrenser for 20 av de hyppigst tilbudte farmakologiske substansene i Norge.

\begin{tabular}{|lll|}
\hline Substans & \multicolumn{2}{l|}{ Måleenhet Grense ${ }^{\mathbf{1 , 2}}$} \\
\hline Ciklosporin & $\mu \mathrm{g} / \mathrm{l}$ & $\leq 50$ \\
\hline Digitoksin & $\mathrm{nmol} / \mathrm{l}$ & $\geq 30$ \\
\hline Digoksin & $\mathrm{nmol} / \mathrm{l}$ & $\geq 2,6$ \\
\hline Etanol & $\%$ & $\begin{array}{l}\text { Ingen } \\
\text { Barn under } 5 \text { år: Alle }\end{array}$ \\
\hline Etylenglykol & $\mathrm{mmol} / \mathrm{l}$ & Alle $^{3}$ \\
\hline Fenobarbital & $\mu \mathrm{mol} / \mathrm{l}$ & $\geq 200$ \\
\hline Fenytoin & $\mu \mathrm{mol} / \mathrm{l}$ & $\geq 100$ \\
\hline Gentamicin & $\mathrm{mg} / \mathrm{l}$ & Ingen \\
\hline Isopropanol & $\mathrm{mmol} / \mathrm{l}$ & Alle \\
\hline Karbamazepin & $\mu \mathrm{mol} / \mathrm{l}$ & $\geq 60$ \\
\hline Litium & $\mathrm{mmol} / \mathrm{l}$ & $\geq 1,5$ \\
\hline Metanol & $\mathrm{mmol} / \mathrm{l}$ & Alle \\
\hline Metotreksat & $\mu \mathrm{mol} / \mathrm{l}$ & $\geq 10$ \\
& & Dosering $1 \mathrm{x}$ per uke: $\geq 0,1$ \\
\hline Paracetamol & $\mu \mathrm{mol} / \mathrm{l}$ & $\geq 500$ \\
\hline Salisylsyre & $\mathrm{mmol} / \mathrm{l}$ & $\geq 4$ \\
& & Barn under 12 år: $\geq 3,5$ \\
\hline Takrolimus & $\mu \mathrm{g} / \mathrm{l}$ & $\leq 3$ \\
\hline Teofyllin & $\mu \mathrm{mol} / \mathrm{l}$ & $\geq 110$ \\
\hline Tobramycin & $\mathrm{mg} / \mathrm{l}$ & Ingen \\
\hline Valproat & $\mu \mathrm{mol} / \mathrm{l}$ & $\geq 900$ \\
\hline Vankomycin & $\mathrm{mg} / \mathrm{l}$ & Ingen \\
\hline
\end{tabular}

${ }^{1}$ Med mindre klinisk farmakolog foretar annen vurdering

${ }^{2}$ Med mindre det foreligger annen avtale med rekvirent

${ }^{3}$ Også negative resultater kan være differensialdiagnostisk viktige 


\section{Noen konkrete problemstillinger}

Vi anbefaler ikke at det varsles om serumkonsentrasjoner av de antimikrobielle legemidlene gentamicin, tobramycin og vankomycin. Behandlingen med disse legemidlene foregår som hovedregel på sykehus, der analyseresultatene foreligger innen relativt kort tid og rutinemessig følges opp av behandlingsansvarlige. Det anses derfor ikke som nødvendig med særskilte varslingsrutiner.

For de toksiske alkoholene (etylenglykol, isopropanol og metanol) anbefaler vi varsling av alle positive prøver. Man kan også vurdere å inkludere varsling av negative prøvesvar i lokale rutiner, siden disse kan være av differensialdiagnostisk betydning.

For etanol har vi i vår interne kartlegging og i drøftingen med ulike kliniske fagmiljøer ikke kommet frem til en allmenn anbefaling vedrørende varsling. På grunn av store individuelle forskjeller i toleranse og sårbarhet for etanol vil grensen for når en gitt etanolkonsentrasjon representerer en potensielt alvorlig forgiftning være svært variabel. Vi har derfor kommet til at vi på generelt grunnlag ikke vil anbefale varsling bortsett fra for barn under fem år, der alle positive prøvesvar bør varsles.

For de immunsupprimerende legemidlene (ciklosporin og takrolimus) medfører subterapeutiske konsentrasjoner økt fare for avstøtningsreaksjoner hos transplanterte. Denne risikoen $ø$ ker dess lavere konsentrasjonen er. Varigheten av den subterapeutiske fasen virker også inn. Arbeidsgruppen mener derfor at det er mest rasjonelt å sette en nedre varslingsgrense for disse substansene.

Vi håper at anbefalingene stimulerer til en mer enhetlig nasjonal praksis for varslingsgrenser.

\section{LITTERATUR:}

1. Farmakologiportalen. Nasjonale referanseområder - prosjektrapporter. www.farmakologiportalen.no/nasjonale_referanseomrader/(4.10.2018).

2. Westin AA, Larsen RA, Espnes KA et al. Legemiddelanalyser i Norge. Tidsskr Nor Legeforen 2012; 132: 2382 - 7. [PubMed][CrossRef]

3. Karlsen Bjånes T, Mjåset Hjertø E, Lønne L et al. Pharmacology portal: an open database for clinical pharmacologic laboratory services. Clin Ther 2016;38: 222 - 6. [PubMed][CrossRef]

4. Farmakologiportalen. Varslingsgrenser for klinisk farmakologiske analyser. http://www.farmakologiportalen.no/attachment.ap?id=16 (4.10.2018).

Publisert: 1. november 2018. Tidsskr Nor Legeforen. DOI: 10.4045/tidsskr.18.0776

Mottatt 5.10.2018, godkjent 16.10.2018.

(C) Tidsskrift for Den norske legeforening 2020. Lastet ned fra tidsskriftet.no 